\title{
Colloquium: The Creative and Expressive Arts in Education, Research and Therapy-Focus on Japan
}

\section{专栏报告 : 创造性和表达性艺术教育、研究和治疗---专注日本}

Colloquium: CAET is pleased to publish submissions from several more contributors to our on-going Colloquium in which authors report on the state of the creative and expressive arts in their respective countries. This issue focuses on Japan. We welcome further reports from other Asian countries.

CAET期刊很高兴地在我们连续栏目《专栏报告》中出版更多作者递交的文章， 以分享报告他们各自国家在创造性和表现性艺术领域的发展状况。本期报告的 焦点是日本。我们欢迎并期待更多来自其他亚洲国家的报告。 